the morning immediately after night duty, rather than later in the afternoon after 31 continuous hours on duty, as we did. This is surely where the moral lies when it comes to considering the implications of our study for clinical practice. It is the long hours of continuous work rather than sleep loss that is the main culprit.

J H GRUZELIER D I ORTON

Department of Psychiatry,

estminster Medical School

London W6 8RF

1 Orton DI, Gruzelier JH. Adverse changes in mood and cognitive performance of house officers after night duty. $\mathrm{Br}$. Med $\mathcal{J}$ 1989;298:21-3. (7 January.)

2 Spurgeon A, Sims J. Lack of sleep in junior doctors. Br Med $\mathcal{F}$ 1989;298:381-2. (11 February.)

3 Cashman JN, Jones H, Skelly AM. Lack of sleep in junior doctors. Br Med f 1989;298:381. (11 February.)

4 Horne JA. Restitution and human sleep: a critical review. Physio Psychol 1979:7:115-25.

5 Gruzelier J, Brow T, Perry A, Rhonder J, Thomas M. Hypnotic susceptibility: a lateral predisposition and altered cerebral susceptility: a lateral predispositon and altered cerebra

6 Cikurel $\mathrm{K}$, Gruzelier JH. The effect of an active-alert hypnotic induction on lateral asymmetry in haptic processing. $B r \mathcal{F} E x p$ Clin Hypnosis (in press).

\section{Aluminium accumulation and immunosuppression}

SIR,-Drs K P Nordal and colleagues and Dr A Davenport and others have recently drawn attention to a possible link between aluminium overload and immunosuppression in renal transplant recipients. ${ }^{12}$

In fact, Silke et al had observed a low incidence of transplant rejection despite poor tissue antigen matching in seven patients with dialysis encephalopathy as early as $1978 .^{3}$ Observations on an extended series including these patients did not confirm the trend, with at least one frank clinical or histological rejection episode occurring in nine of 23 transplanted encephalopathic patients, and high dose steroids given to a further nine for suspected rejection. ${ }^{+}$Fifteen patients, however, developed bacterial or cytomegalovirus infection, contributing to death in 13 , and the dose of azathioprine required adjustment because of leucopenia in nine cases. Furthermore, four patients displayed low serum IgA concentrations. Of the last six patients in the series, five subsequently did well with good graft function at least 12 months after transplantation. Possible factors in the improved prognosis included an embargo on aluminium for at least six months before transplantation and careful attention to calcium balance in the postoperative period. Though these observations are consistent with an immunosuppressive effect of aluminium, further work needs to be done on cellular and humoral immunity in patients with aluminium overload. Transplantation is an effective treatment for patients with frank clinical aluminium intoxication, but the aluminium burden should be first reduced by an embargo and possibly desferrioxamine chelation treatment.

PETER GARRETT

Wessex Regional Renal Unit,

St Mary's Hospital,

Portsmouth,

Hampshire PO36AD

1 Nordal KP, Dahl E, Albrechtsen D, et al. Aluminium accumulation and immunosuppressive effect in recipients of kidney transplants. Br Med f 1988;297:1581-9. (17 December.)

2 Davenport A, Toothill C, Davison AM, Newton KE, Will EJ, Giles GR. Aluminium accumulation and immunosuppression. BrMed f 1989;298:458-9. (18 February.)

3 Silke B, Fitzgerald GR, Hanson S, Carmody M, O'Dwyer WF. Dialysis dementia and renal transplantation. Dialysis and Dialysis dementia and renal
Transplantation 1978;7:486-7.

4 Garrett PJ. Aluminium poisoning. (MD thesis.) Liverpool: University of Liverpool, 1985

5 Garrett PJ, Mulcahy D, Carmody M, O'Dwyer WF. Aluminium encephalopathy: clinical and immunological features. $Q \mathcal{J} \mathrm{Med}$ 1988;69:775-83.

\section{Necrosis of skin induced by coumarin}

SIR, - The article by Dr Vito Grimaudo and colleagues on skin necrosis induced by coumarin attracted our attention as coumarin itself could have been used to treat the necrotic lesions. Many patients with cancer are treated with the dicoumarin type oral anticoagulants warfarin and nicoumalone (Sinthrome), ${ }^{2}$ and any necrotic lesions that develop are treated by local application of coumarin. Coumarin is also used to prevent skin necrosis in herpes zoster and herpes simplex. "Sister Majella's cold sore cream," which is $1 \%$ coumarin in Silcock's base, has been used for years in our hospitals. In Switzerland coumarin is used to treat and prevent oedema, ${ }^{3}$ and it is marketed there by Schaper and Brummer (Saltzgitter, Federal Republic of Germany) under the name of Venalot.

Dicoumarin type oral anticoagulants are often referred to as coumarin, but coumarin (1,2 benzopyrone) has no anticoagulant action. It is a macrophage stimulant, ${ }^{+}$enhancing proteolytic activity, and it is used in treating melanoma ${ }^{5}$ and renal cell carcinoma. ${ }^{6}$ Coumarin is also being investigated in treating intracellular infection such as brucellosis, tuberculosis, and leprosy because of its macrophage stimulating effect.

Recently, at the Ganta Leprosy Center in Liberia 24 patients with leprosy who had a total of 32 indolent necrotic ulcers resulting from burns were treated successfully with 1\% coumarin in Silcock's base. It not only promoted healing but also reduced the smell and the flies, and these patients no longer need to be isolated. Both the patients and the staff were impressed and grateful.

$M$ CHAMBERS R D THORNES M MCKERNAN

Medical Missionaries of Mary

International Missionary Training Hospital,

Drogheda,

Republic of Ireland

1 Grimaudo V, Gueissaz F, Hauert J, Sarraj A, Kruithol J Bachmann $F$. Necrosis of skin induced by coumarin in patient deficient in protein S. Br Med J 1989;298:233-4. (28 January.

2 Hilgard P, Thornes RD. Anticoagulants in the treatment of ancer. Eur f Cancer 1976;12:755-61.

Clodius L, Piller NB. Conservative therapy for post-mastectom ymphoedema. Chirurgica Plastica 1978:4:193-6.

4 Pillar NR. The ineffectiveness of coumarin treatment on therma edema of macrophage free rats. $B r f$ Exp Pathol 1976;57: $170-5$.

5 Thornes RD, Lynch G, Sheehan MV. Cimetidine and coumarin therapy of melanoma. Lancet 1982;ii:328.

6 Marshall ME, Mendelsohn L, Butler K, et al. Treatment of metastatic renal cell carcinoma with coumarin $(1,2$ benzopyrone) and cimetidine: a pilot study. $\mathcal{I}$ Clin Oncol 1987;5: $862-6$

7 Thornes RD. Acquired immune suppression in chronic brucellosis. Irish Med f 1983;26:225.

\section{Spina bifida occulta and functional disorders of the lower urinary tract}

SIR, - We compliment Mr A Fidas and colleagues on their excellent paper, ' which at last provides hard numerical data to support our own clinical conviction that spina bifida occulta is a common anomaly found in urological patients and which should therefore be reported by radiologists.

The authors have, however, overlooked our presentation at the June 1987 meeting of the British Association of Urological Surgery, where we reviewed published reports on spina bifida occulta in relation to enuresis and drew attention to their inadequacies. In patients referred for intravenous urograms from a urological clinic we found hat $14 \cdot 3 \%$ showed spina bifida occulta on the precontrast film compared with $7 \cdot 4 \%$ of controls having plain abdominal radiographs $(\mathrm{p}<0.01)$ using West's criteria for spina bifida occulta. ${ }^{2}$ Furthermore, $87 \%$ of those with spina bifida occulta had a V shaped puddle of contrast on the bladder films in the bladder neck region $(p<0 \cdot 001)$. This we called the funnel neck sign as it was a radiological correlate of the funnel neck deformity of the bladder seen cystoscopically and described by MacAlpine in his presidential address to the Royal Society of Medicine.

We have associated this deformity with a clinical syndrome which includes increased frequency of micturition, diurnal incontinence, enuresis, and urinary tract infections. Of 300 consecutive patients identified as having the funnel neck deformity on intravenous urography or cystoscopy, or both, $215(71 \%)$ had spina bifida occulta grade $\mathrm{S} 1$. We also found $60(20 \%)$ who had six lumbar vertebrae whereas only four out of 250 controls had this $(2 \%)$.

It would be interesting for the authors to review the intravenous urograms of their 138 patients looking for this sign and in future to search for the funnel neck sign on cystoscopy as part of their usual urological and radiological assessment and for radiologists to report on the state of the lumbosacral spine.

Children's Hospital,

P N HALL

Birmingham,

M H HALL

Whipps Cross Hospital

London E11

I Fidas A, MacDonald ML, Elton RA, McInnes A, Wild SR, Chisholm GD. Prevalence of spina bifida occulta in patients with functional disorders of the lower urinary tract and its relation to urodynamic and neurophysiological measurements. BrMed f 1989;298:357-9. (11 February.)

2 West JW. An investigation into the relation between enuresis and spina bifida occulta. $\mathcal{J} R$ Army Med Corps 1927;48:38-45.

MacAlpine JB. The musculature of the bladder neck of the male in health and disease. Proc $R$ Soc Med 1934;28:39:56.

\section{Disaster planning}

SIR, - In Editor's Choice last week' you identified the lack of national policies on disaster management and suggested that we needed a conference where people with experience could pool their ideas. Such a conference is being held in Stoke on Trent on 2-3 June 1989. Speakers with direct experience have been chosen to talk on the medical response to major disasters both at home and abroad, and discussions will be aimed at defining effective policies for the future. Details may be found in the advertisement in this issue (see Clinical Research classified supplement).

JOANNA PORTER ELIZABETH TAYLER JOHN TEMPLETON PETER THOMAS

North Staffordshire Roval Infirmary, Stoke on Trent ST 4 7LN

1 Anonymous. Editor's choice. Br Med f 1989;298. (11 March.)

\section{Correction}

Cervical intraepithelial neoplasia in women with renal allografts

A printer's error occurred in this letter by Dr Micheline Byrne and others (4 March, p 599). In the third line of the fourth paragraph the sentence: ". . . women with human papillomavirus infection who have not yet developed AIDS . ..." should have read: “. . . women with human immunodeficiency virus infection who have not yet developed AIDS." 